\title{
Luteal regression, follicle growth and the concentration of some plasma steroids during lactation in grey seals (Halichoerus grypus)
}

\author{
I. L. Boyd* \\ Sea Mammal Research Unit, Natural Environment Research Council, c/o British Antarctic Survey, \\ Madingley Road, Cambridge CB3 OET, U.K.
}

\begin{abstract}
Summary. Ovaries of lactating grey seals, which had been shot, were measured to obtain the size of each follicle and corpus luteum. Plasma samples were collected by temporarily immobilizing lactating females. The single corpus luteum regressed rapidly after pupping and circulating progesterone levels declined at parturition and remained low throughout most of lactation. A single wave of follicular growth began about the time of parturition and gave rise to a single mature follicle towards the end of lactation. This coincided with high plasma oestradiol-17 $\beta$ concentrations and behavioural oestrus. A corpus luteum inhibited follicular growth in the ipsilateral ovary. The concentration of plasma progesterone increased in some seals late in lactation, indicating that ovulation sometimes occurred before the end of lactation. This was confirmed by observation of ovaries from shot seals.
\end{abstract}

\section{Introduction}

Reproduction in grey seals is highly seasonal. Parturition, which takes place in autumn on the coast of Britain, occurs in colonies located on isolated islands. Gestation, which lasts about 350 days, includes a period of embryonic diapause of about 150 days (Hewer \& Backhouse, 1968). Oestrus and mating occur 14-18 days after parturition (Boness \& James, 1979). Weaning of the single pup is marked by a sudden change from normal maternal behaviour (Fogden, 1971; Anderson, Burton \& Summers, 1975) to complete desertion of the pup after oestrus. The survival of the pup will be dependent upon the level of maternal care received during lactation and is proportional to the length of lactation (Fedak \& Anderson, 1982). Female grey seals which give birth and fail to lactate leave the pupping colony within a few days and are not mated before leaving. There is therefore no observational evidence to suggest that the timing of oestrus is dependent upon the success or failure of lactation.

In this study the pattern of follicle development in the ovaries of lactating grey seals was investigated to determine whether the occurrence of lactation is inhibitory to follicle growth and ovulation. An experimental approach was not possible due to the paucity of captive experimental animals and the inherent difficulties of working on free-living grey seals. As a result, this study relies on observational data.

* Present address: Institute of Terrestrial Ecology, Monks Wood Experimental Station, Abbots Ripton, Huntingdon, Cambridgeshire PE17 2LS, U.K. 


\section{Materials and Methods}

Collection and analysis of ovaries

Ovaries were collected from 249 lactating female grey seals at the Farne Islands during a population management cull in November 1972. Each pair of ovaries was fixed in $4 \%$ buffered formaldehyde.

Ovaries were sliced serially along the longitudinal axis to expose the cortex and most of the medulla. Each slice was about $2 \mathrm{~mm}$ thick and slices were cut in such a way as to retain their attachment to the medulla or the remainder of the suspensory ligament so that the relationship of the sections was not lost. The surfaces of each section were inspected in sequence. The maximum diameter of the largest follicle in each ovary was measured to the nearest millimetre and antral follicles were classified according to their size. Five size classes were used : 3-6 mm, 6-9 mm, 9-12 $\mathrm{mm}, 12-15 \mathrm{~mm}$ and $>15 \mathrm{~mm}$. Follicles $<3 \mathrm{~mm}$ in diameter were not included because they could not be counted accurately. The shape of corpora lutea $(\mathrm{CL})$ varied greatly from one seal to another. The best index of CL size was obtained from the average of three diameters, measured vertically, horizontally and longitudinally to the nearest millimetre. Forty-six of the lactating females in this sample were shot at an estimated time from parturition. This estimate was accurate to the nearest whole day for seals shot early in lactation and to within 2 days for seals shot late in lactation. Luteal regression post partum was shown by plotting the mean diameter of the CL of each of these seals with the estimated time of capture relative to parturition. The size of the $C L$ from females collected at an unknown stage of lactation was used to indicate the stage of lactation in these females. Thin sections of some ovaries were taken for histological examination.

\section{Blood sampling}

Venous blood samples were obtained from 35 lactating female grey seals at the North Rona pupping colony. It was more convenient to use these seals rather than seals at the Farne Islands and it is unlikely that any difference existed between these colonies that would influence the results. Seals were marked soon after parturition and immobilized with a mixture of ketamine hydrochloride (Parke, Davis \& Co., Usk Road, Pontypool, Gwent, U.K.) and xylazine (Bayer U.K. Limited, Agrochem. Division, Eastern Way, Bury St Edmunds, Suffolk, U.K.) (Parry, Anderson \& Fedak, 1981) at various stages of lactation. Most were immobilized on more than one occasion and some were immobilized up to 4 times. Blood $(10-20 \mathrm{ml})$ was collected from the hind flipper into heparinized 'Vacutainers' (Becton \& Dickinson, Between Towns Road, Cowley, Oxford OX4 3LY, U.K.), centrifuged within $6-8 \mathrm{~h}$ and stored frozen at -20 to $-30^{\circ} \mathrm{C}$.

\section{Hormone determinations}

Plasma concentrations of progesterone, oestrone and oestradiol-17 $\beta$ were determined by radioimmunoassay after the purification of plasma extracts by reverse phase chromatography on celite columns (Abraham, 1975). Plasma (1 ml) was extracted with 6 volumes of peroxide-free diethyl ether and separated into two fractions on celite columns using spectrosol iso-octane as the solvent. Ethyl acetate was used to adjust the solvent polarity to give one fraction containing progesterone and the other oestrone and oestradiol $-17 \beta$. Labelled steroid applied directly to the column was recovered as $98.4 \pm 2.9 \%$ progesterone, $90 \cdot 4 \pm 3.2 \%$ oestrone and $80.5 \pm 3.0 \%$ oestradiol-173. Extracts of seal plasma with added labelled steroid gave recoveries after chromatography of $87.6 \pm 1.6 \%$ for progesterone, $46.0 \pm 1.8 \%$ for oestrone and $42.8 \pm 2.2 \%$ for oestradiol-17 $\beta$. The results were corrected for these procedural losses. The progesterone fraction contained $16.7 \%$ of the oestrone and $1.0 \%$ of the oestradiol $17 \beta$ while the oestrogen fraction contained $3.0 \%$ of the progesterone. Extractions were not duplicated, but each fraction was split and assayed in duplicate for the three steroids such that the concentration in the assay tube was 
equivalent to plasma extractions of $0.5 \mathrm{ml}$ for progesterone, $0.2 \mathrm{ml}$ for oestrone and $0.3 \mathrm{ml}$ for oestradiol-17 3 . Nine assays were carried out for each steroid, the details of which are given in Table 1. The cross-reactions for the progesterone antibody have been described by Sheldrick, Ricketts $\&$ Flint (1980); the major reactants were 11-deoxycorticosterone (4.0\%), 5 $\alpha$-pregnanedione $(2.0 \%)$ and pregnenolone $(1.5 \%)$. The oestrone antibody (Steranti E001) cross-reacted mainly with oestradiol-17 $(0.5 \%)$, equilin $(6.0 \%)$ and equilenin $(3.0 \%)$. The oestradiol- $17 \beta$ antibody $(510 / 5$, Institute of Animal Physiology, Babraham) cross-reacted mainly with oestrone $(6.0 \%)$, epioestriol $(0.3 \%)$, and testosterone $(1.2 \%)$. The plasma samples were not assayed in the order of sampling so that any continuous or discontinuous bias within the assays would not be reflected in the values obtained. The assay blank was not subtracted before calculating the steroid concentration in each sample.

Table 1. The specifications for the progesterone, oestrone and oestradiol- $17 \beta$ radioimmunoassays

\begin{tabular}{|c|c|c|c|}
\hline & Progesterone & Oestrone & Oestradiol-17 $\beta$ \\
\hline Inter-assay coefficient of variation & $15 \cdot 8 \%$ & $11 \cdot 8 \%$ & $9 \cdot 1 \%$ \\
\hline Intra-assay coefficient of variation & $9.7 \%$ & $13.2 \%$ & $14.6 \%$ \\
\hline $\begin{array}{l}\text { Sensitivity* (minimum detectable } \\
\text { quantity/tube) }\end{array}$ & $0.042 \pm 0.007 \mathrm{ng}$ & $65 \cdot 0 \pm 14 \cdot 2 \mathrm{pg}$ & $6.0 \pm 1.3 \mathrm{pg}$ \\
\hline Standard range & $0.01-3.2 \mathrm{ng}$ & $15-500 \mathrm{pg}$ & $4-240 \mathrm{pg}$ \\
\hline $\begin{array}{l}\text { Assay blank value } \\
\text { (ovariectomized goat plasma) }\end{array}$ & $0.012 \pm 0.005 \mathrm{ng}$ & $3.7 \pm 2.0 \mathrm{pg}$ & $4.25 \pm 0.8 \mathrm{pg}$ \\
\hline
\end{tabular}

* As defined by Bolton et al. (1975).

\section{Results}

\section{Corpus luteum regression and follicle growth}

Each of the females sampled had a single CL. In all the seals examined, pregnancy had occurred in the uterine horn which was ipsilateral to the ovary containing the CL. In those individuals sampled at a known time from parturition, the CL declined in size during lactation (Text-fig. la). The reduction in $\mathrm{CL}$ size was accompanied by a loss of vascularity and fibrosis of the gland. The apparent linearity of a reciprocal transformation applied to the CL diameter with time from parturition (Text-fig. 1b) shows that the regression followed a hyperbolic relationship (Sokal \& Rohlf, 1981). The variation along the regression of the reciprocal CL diameter showed little decrease with increased time from parturition, suggesting that the slope of the curve (s.e. = 0.00013 ) is an accurate representation of the rate of CL regression. Based on the curve in Text-fig. 1(b), it is then possible to use the size of the CL to obtain an approximate estimate of the time from parturition $(95 \%$ confidence limits $= \pm 5.313$ days) when this is not known. While the error on this estimate is large, the large sample size of lactating females used $(\mathrm{N}=249)$ will cause the sample mean of estimates to converge with the population mean.

Using the size of the CL to estimate the stage of lactation in the whole sample of 249 females, the diameter of the largest follicle in the ovary containing the CL was not as great as the diameter of the largest follicle in the contralateral ovary at any stage of lactation (Text-fig. 2). The CL in each seal was placed in one of 12 size classes, each one of which represented an increment of $1 \mathrm{~mm}$ in the mean diameter of the CL. There was no clear increase or decrease in the diameter of the largest follicle in the ovary containing the CL. The size of the largest follicle in the opposite ovary increased continuously from early in lactation to reach a mean diameter of 13-16 $\mathrm{mm}$ towards the end. The presence of a CL in an ovary appeared directly or indirectly to influence follicular growth and development. 


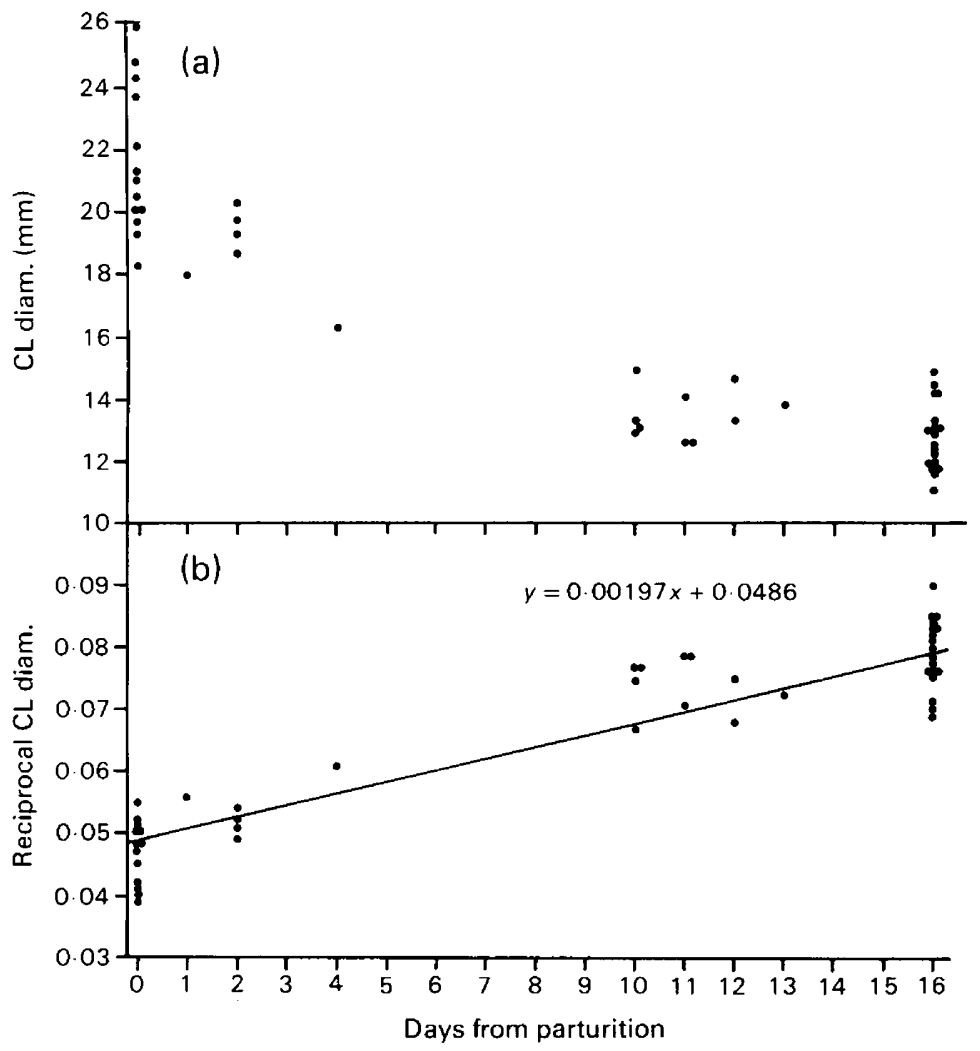

Text-fig. 1. The mean diameter of the corpus luteum (a) and the reciprocal diameter of the corpus luteum (b) as a function of the time from parturition for females sampled at a known time from parturition.

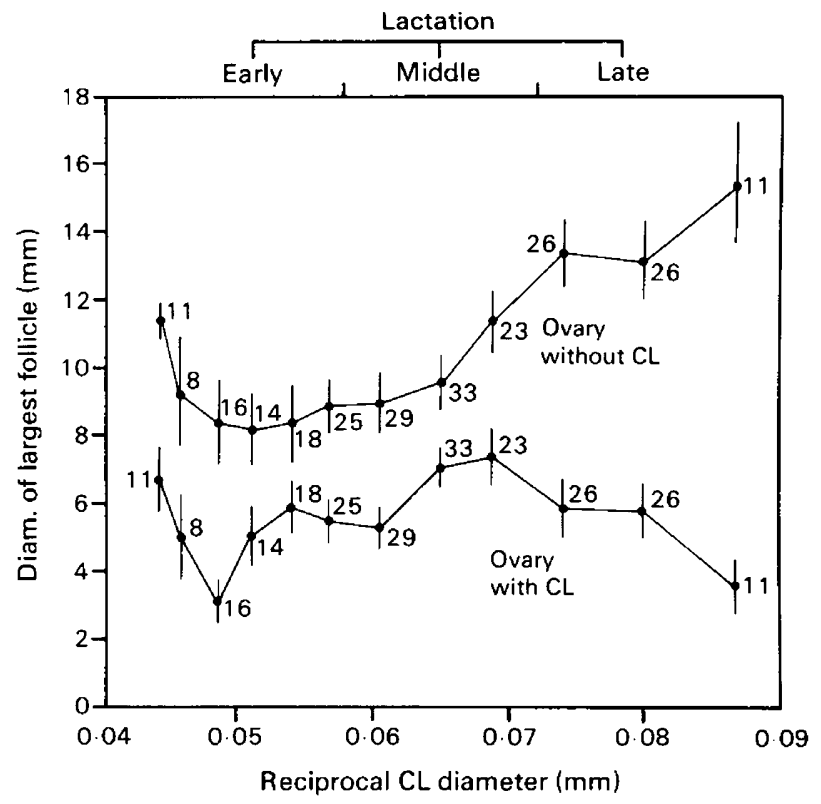

Text-fig. 2. The mean diameter ( \pm l s.e.m.) of the largest follicle in each ovary as a function of the reciprocal luteal diameter. Females were classified according to the mean CL diameter ( $1 \mathrm{~mm}$ size classes). Sample sizes are shown. 
The curves in Text-fig. 2 may represent follicular growth in terms of single follicles or as a series of waves of follicular growth, each one terminating in a slightly later developmental stage than its predecessor. Considering first the ovary contralateral to that with the CL, follicles of size class 1 (3$6 \mathrm{~mm}$ ) were most abundant at the beginning of lactation and there was a linear decline in their abundance from an average of 20 per ovary to about 5 per ovary during lactation (Text-fig. 3 ). The frequency of follicles of size class $2(6-9 \mathrm{~mm})$ increased to a maximum during the first half of lactation and declined to about 2 follicles per ovary in the later stages. There was little discernible pattern in the frequency of follicles in size class $3(9-12 \mathrm{~mm})$ but follicles of size class $4(12-15 \mathrm{~mm})$ increased in frequency during the first half of lactation and were also fairly abundant $(0.5$ follicles/ovary) for much of the second half, although there was a slight decline very late in lactation. Follicles in size class $5(>15 \mathrm{~mm})$ increased in frequency from early in lactation to an average of $0.6-0.8$ /ovary towards the end. The divisions between the follicle size classes were empirical and by combining size classes 4 and 5 females had on average just over one follicle $>12$ $\mathrm{mm}$ in diameter throughout the final third of lactation. These data show that there was a single

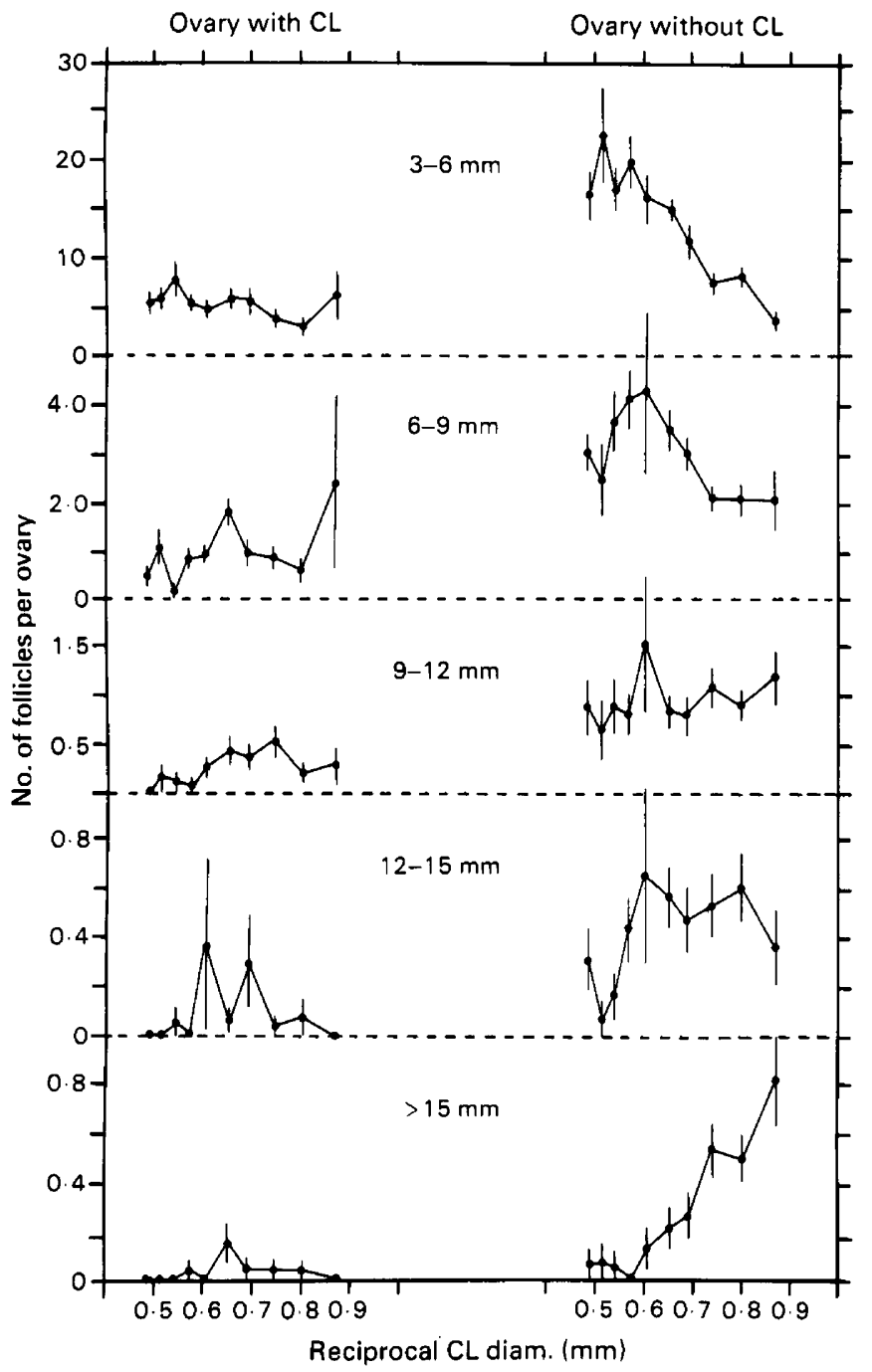

Text-fig. 3. The mean numbers of follicles ( \pm 1 s.e.m.) of different size classes in each ovary as a function of the reciprocal CL diameter. Sample sizes are the same as those given in Text-fig. 2 . 
wave of follicular growth during lactation, ensuring that there was at least one mature follicle in an ovary towards the end of lactation.

The frequency of follicles in each size class was lower in the ovary with the CL than in the contralateral ovary (Text-fig. 3). There was no equivalent increase in the frequency of small follicles early in lactation in this ovary as was observed in the ovary not having the $C L$, indicating that there was a high rate of atresia during the early phase of follicle growth or fewer follicles were reactivated in the ovary with the CL.

While there was no certain method of distinguishing healthy and atretic follicles in macroscopic section, histological examination of some ovaries suggested that once a follicle became atretic it involuted rapidly. Relatively few stages of atresia between the healthy stage and the scar of the follicle were observed, suggesting that these stages were passed through relatively rapidly. Hence, few of the counted follicles would have been atretic.

\section{Plasma steroids}

Plasma samples taken from free-living grey seals showed that females had a high concentration of plasma oestradiol-17 $\beta$ late in lactation which coincided with the time when the majority of females would be expected to be in oestrus. In samples obtained 15-18 days after parturition there were two clear groups; those in which the concentrations of progesterone were high and of oestradiol-17 $\beta$ low, and the others in which concentrations of progesterone were low and of oestradiol high (Text-fig. 4). The concentration of unconjugated oestrone remained low throughout lactation.
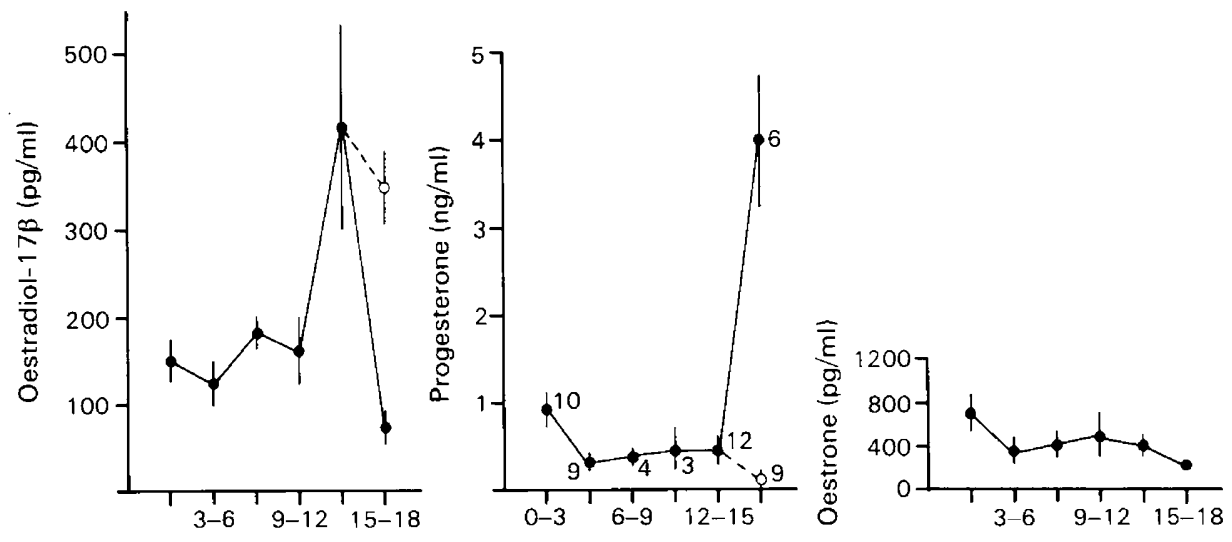

Days from parturition

Text-fig. 4. Mean \pm 1 s.e.m. plasma concentration of oestradiol-17 $\beta$, progesterone and oestrone during lactation in grey seals. Females having elevated oestradiol-17 $\beta$ and low progesterone (O) are distinguished from those having low oestradiol-17 $\beta$ and high progesterone (O) at the end of lactation. Sample sizes are shown.

\section{Discussion}

The CL of grey seals grows rapidly during the final few months of gestation (Boyd, 1982). It is not known whether the $\mathrm{CL}$ is necessary for the maintenance of progesterone levels in late pregnancy, but declining plasma progesterone concentrations and the subsequent involution of the CL coincide with parturition. Laws (1956) also found that the CL of the southern elephant seal (Mirounga leonina) regressed rapidly during lactation. The influence of a regressing $\mathrm{CL}$ on follicular growth in the ipsilateral ovary indicates that ovulation is probably from alternate ovaries 
in consecutive years. Such an alternation appears to be common in pinnipeds (Laws, 1956; Craig, 1964; Øritsland, 1964; Harrison, 1964).

There was a clear wave of follicular growth, initiated about the time of parturition, which led to the production of very large follicles during the late stages of lactation. This pattern of follicular development related well with changes in the concentration of plasma oestrogens and the timing of oestrous behaviour (Boness \& James, 1979). If the rate of follicular growth is constant, changes in the length of lactation or desertion of the pup at an early stage are unlikely to affect the time of oestrus.

The high progesterone titre in some seals late in lactation correlates with the weaning of the pup and is taken to indicate that ovulation had already occurred in these females. A small number of seals in the sample from the Farne Islands had also ovulated. Considering that grey seals have an obligatory period of embryonic diapause (Hewer \& Backhouse, 1968), the high post-ovulatory progesterone titre is surprising. However, plasma taken from grey seals during diapause also showed that progesterone was elevated $(4-6 \mathrm{ng} / \mathrm{ml})$ throughout this period. In northern fur seals (Callorhinus ursinus), in which oestrus and mating occur within a few days of parturition and lactation may last several months (Craig, 1964; Gentry, 1981), progesterone levels also remain low throughout lactation although most females are pregnant at this time (Daniel, 1975). Therefore, progesterone levels are low in northern fur seals and grey seals throughout lactation but they only remain low throughout diapause in northern fur seals.

Suckling may have a negative feedback effect on gonadotrophin release and inhibit oestrus and ovulation to some extent, but the frequency or intensity of suckling does not decline towards the end of lactation (Fogden, 1971). Therefore, it must be assumed that lactational inhibition of gonadotrophin release declines after a time or that no such inhibition exists and the timing of oestrus is independent of the occurrence of lactation. This may be a universal feature of all seals in the family Phocidae since the occurrence of a lactational oestrus is found in many species (Laws, 1956; Burns, 1970; Smith, 1973; Øritsland, 1975; Stewart \& Lavigne, 1980).

I thank the present and past staff of the Sea Mammal Research Unit who collected many of the ovaries considered in this study; and Dr R. B. Heap and Dr A. P. F. Flint for assistance with the steroid radioimmunoassays while I was visiting the Institute of Animal Physiology, Babraham. This study was financed by the Natural Environment Research Council.

\section{References}

Abraham, G.E. (1975) Use of diatomite microcolumns for the chromatographic separation of steroids prior to radioimmunoassay. Path. Biol. 23, 889-893.

Anderson, S.S., Burton, H.W. \& Summers, C.F. (1975) Behaviour of grey seals (Halichoerus grypus) during the breeding season at North Rona. J. Zool., Lond. 177, 179-195.

Bolton, A.E., Dighe, K.K. \& Hunter, W.H. (1975) Steroid antibody immunoadsorbents. In Steroid Immunoassay, pp. 257-267. Eds E. H. D. Cameron, S. G. Hillier \& K. Griffiths. Alpha Omega Publishing Ltd, Cardiff.

Boness, D.J. \& James, H. (1979) Reproductive behaviour of the grey seal (Halichoerus grypus) on Sable Island, Nova Scotia. J. Zool., Lond. 188, 477-500.

Boyd, I.L. (1982) The use of corpora albicantia for the determination of pregnancy rates in seals with special reference to grey seals (Halichoerus grypus). International Council for the Exploration of the Sea. CM 1982/N:14, 10 pp.
Burns, J.J. (1970) Remarks on the distribution and natural history of pagophilic pinnipeds in the Bering and Chukchi Seas. J. Mammal. 51, 445-454.

Craig, A.M. (1964) Histology of reproduction and the oestrous cycle in the female fur seal, Callorhinus ursinus. J. Fish. Res. Bd Can. 21, 773-811.

Daniel, J.C., Jr (1975) Concentrations of circulating progesterone during early pregnancy in the northern fur seal, Callorhinus ursinus. J. Fish. Res. Bd Can. 32, 65-66.

Fedak, M.A. \& Anderson, S.S. (1982) The energetics of lactation: accurate measurements from a large wild mammal, the grey seal. J. Zool., Lond. 198, 473-479.

Fogden, S.C.L. (1971) Mother-young behaviour at grey seal breeding beaches. J. Zool., Lond. 164, 61-92.

Gentry, R.L. (1981) Northern fur seal-Callorhinus ursinus. In Handbook of Marine Mammals, vol. 1, pp. 143-160. Eds S. H. Ridgway \& R. J. Harrison. Academic Press, London. 
Harrison, R. J. (1964) Delayed implantation-a curious reproductive phenomenon. Proc. $R$. Instn Gr. Br. 40, $143-158$.

Hewer, H.R. \& Backhouse, K. (1968) Embryology and foetal growth rate in the grey seal (Halichoerus grypus). J. Zool., Lond. 155, 507-533.

Laws, R.M. (1956) The elephant seal (Mirounga leonina Linn.). III. The physiology of reproduction. Scient. Rep. Falkland Isl. Depend. Surv. No. 15, 66 pp.

Oritsland, T. (1964) Klappmysshumnens forplantingsbiologi (breeding biology of the hooded seal). Fiskets gang. Arg. 50, 5-19.

Oritsland, T. (1975) Sexual maturity and reproductive performance of female hooded seals at Newfoundland. ICNAF Research Bulletin 11, 37-41.
Parry, K., Anderson, S.S. \& Fedak, M.A. (1981) Chemical immobilisation of gray seals. J. Wildl. Manage. 45, 986-990.

Sheldrick, E.L., Ricketts, A.P. \& Flint, A.P.F. (1980) Placental production of progesterone in ovariectomised goats treated with a synthetic progestagen to maintain pregnancy. J. Reprod. Fert. 60, 339-348.

Smith, T.G. (1973) Population dynamics of the ringed seal in the Canadian Arctic. Bull. Fish. Res. Bd Can. No. $181,55 \mathrm{pp}$.

Sokal, R.R. \& Rohlf, F.J. (1981) Biometry. Freeman, San Francisco.

Stewart, R.E.A. \& Lavigne, D.M. (1980) Neonatal growth of northwest Atlantic harp seals, Pagophilus groenlandicus. J. Mammal. 61, 670-680.

Received 13 January 1983 